UDK 821.163.6(71)-31.09Kramolc T.

\title{
SLOVENIAN DIASPORIC LITERATURE IN CANADA AND TED KRAMOLC
}

\author{
Igor Maver
}

\begin{abstract}
The article analyzes the work and especially the novels by the Canadian writer of Slovenian descent, Ted Kramolc. It places him within the context of other diasporic literary authors in Canada as well as the Slovenian cultural space and discusses the critical response to his work, particularly in the period after Slovenian independence.
\end{abstract}

Key words: Slovenian diasporic Literature, Canadian literature, Ted Kramolc

In Memory of Ted Kramolc (1922-2013) and Mirko Jurak (1935-2014)

The most comprehensive study of Slovenian literary creativity in Canada was carried out by Mirko Jurak (1935-2014), published in the first ever multi-volume monumental study of all Slovenian emigrant literature, in the book on North America, Slovenska izseljenska književnost: Severna Amerika (Jurak 1999; 2005). Jurak was, a professor of literatures in English at the Faculty of Arts of the University of Ljubljana, who knew Ted Kramolc (1922-2013) and many other Canadian authors of Slovenian descent very well, who regularly corresponded with them and also helped them publish in Slovenia.

Much has already been written about Slovenian migration to Canada, the social, religious and cultural activities of the Slovenian diaspora and their descendants in Canada and their press. Since 1996 especially The Slovenian: Glasilo Magazine (edited by Cvetka Kocjančič) "has provided news, literature and commentary for and about Canadians of Slovenian heritage" (www.theslovenian.com). Sketches (a typical Slovenian short fiction form), short stories and novels are the most frequently used literary forms by Slovenian diasporic authors in Canada. Ted Kramolc, Ivan Dolenc, Cvetka Kocijančič, Irma Ožbalt and Ludve A. Potokar (Jurak 1999: 339) are aesthetically the most prominent ones, although there have been scores of other prose writers who have published their usually shorter pieces in newspapers, journals and books: Janez Kopač, Franc Sodja, Tone Zrnec, Tone Zagorc, Rudolf Cuješ, Miro Rak, Franc Grmek, Lojzka Saje, Marija Koprivšek, Nataša Kolman, Dore Sluga, Franc Skumavc, Anthony Am- 
brozic, Stanislav Pleško, Danica Dolenc etc. Many of these writings are based on the sad and terrible experiences of the authors/fictional characters during and immediately after the Second World War, when they had to flee their Slovenian homeland as political refugees through Austria to finally settle and find peace and freedom in Canada. Miro Rak and Franc Grmek, on the other hand, in the short stories and sketches described their adventurous experiences in hunting and fishing in Canadian wilderness in several collections of stories written in Slovenian. John Krizanc, who does not however consider himself part of the Slovenian diaspora in Canada despite his partly Slovenian roots (his father was born in Trst/Trieste), is a successful dramatist writing in English and certainly part of the mainstream (cf. Jurak 1999; 2005). He co-founded the Necessary Angel Theatre Company and received the Governor General's Award for his play Prague.

Božidar Ted Kramolc (1922-2013) went to Austria in 1945 as a refugee after the end of the Second World War from the changed political system in Slovenia as a constitutive part of the newly formed socialist state of Yugoslavia. Displaced in Austria for three years, he came to Canada in 1948. Schooled as a painter and an architect he has lived a great part of his life in Toronto where he still continues to teach painting, painting in his own right and writing, of course: his numerous works are on display in the National Art Gallery in Ottawa, the Art Gallery of Ontario, the Art Gallery of Hamilton etc. Kramolc, a well established painter-writer, which shines through in his style of writing, sees himself and for that matter all people very much defined by the spaces which we inhabit. He describes Canada and Slovenia in these terms: "Slovenia is a nice, enclosed, controlled space: neat houses, charming hills and mountains carefully distributed among lakes, rivers and meadows. But Canada demands a different perspective: wild untamed forests, grand expanses of never ending prairie, savage peaks of solid rock. Nature in Canada is writ large: immense, enormous, and uncaring. Yet breathtakingly beautiful" (qtd. in Urbančič 2008). He enthusiastically welcomed the formation of the independent state of Slovenia in 1991 and in 1992 a selection of short stories came out under the title Podobe iz arhivov (Images from the Archives; Kramolc 1992). They are linked together by the main protagonist who is also the narrator and the people appearing in them are displaced persons, D.P.'s from the refugee camps all over Austria after World War Two that Kramolc himself knew during his own refugee years in Austria. The stories are largely autobiographical as they end with the protagonist's arrival in Canada and establishing himself as an architect specializing in interior decoration. Kramolc wrote many sketches and short stories in English, although his novels are written in Slovenian. The important thing about his work is that it is not just about the emigrant experience but about the meaning of Man's existence as such; also it is largely devoid of political ideology and very independent and original, which is why 'the Slovenian 'political emigration' more than once reproached him for having estranged from it and for having avoided it (not merely in art but also personally)" (Jurak 1999: 352). He wrote poems and short stories (in English and Slovenian), which were published in Slovenian presses especially after 1991, before that also in Slovenian migrant press and anthologies in Argentina and the USA.

He wrote three novels, all of which were written in Slovenian and were published by major Slovenian publishing houses: for one of them he was shortlisted for the prestigious Kresnik Prize for the contemporary Slovenian novel. The novel Potica 
za navadni dan (A Cake for an Ordinary Day; Kramolc 1997) is set in Canada during 1986 and 1996 with four Slovenian married couples in the first part and the focus on one of the women protagonists, Sonja Zavrtanik, and the retired Canadian colonel Tyrone Harrington in the second. The Slovenians in the first part of the book constantly reflect on the Second World War and their role in it, their flight from the newly emerged socialist one-party political system in the former Yugoslavia, the lost years in refugee camps in Austria and finally their emigration to Canada, they are labelled by Kramolc as "professional Slovenians", whose main preoccupation is politics, and consequently there is no place among them for people who think very independently and critically about this situation (e. g. Gorazd Prunk). "Potica", the typical Slovenian walnut cake, which is traditionally made and eaten for holidays and special occasions does not taste the same to them in Canada: it is more sour because the Slovenians brought with them too much hatred. In the second part Sonja and Tyrone, who dies a meaningless death in a bank robbery, are as a loving couple despite their kindred souls shown as 'betraying' each other in their minds by thinking about their former partners (Jurak 1999: 356). The constant shifts of narrative and the downright postmodern technique of this novel do not lead to a happy ending and a vision of a happy coexistence of the two cultures, Slovenian and Canadian. Slovenians in Canada often think very highly of themselves, although they are shown here to be really torn by envy and hypocrisy.

Tango v svilenih coklah (Tango in Silk Clogs; Kramolc 2002) is the author's second novel which was in 2003 nominated for the prestigious Slovenian literary Kresnik Prize. It is a story about a femme fatale model and a painter-migrant which definitely transcends the typical emigrant subject-matter. According to Kramolc himself "clogs in the novel are symbolically coated with silk, which is to cover the filth, stench and decadence of contemporary society" (Kramolc 2003). In his most recent novel set in Canada, Sol v grlu (Salt in Throat; Kramolc 2008) Ted Kramolc revisits the past in a graduated dramatic style, the atrocities of the Second World war and especially the Austrian political refugee camp after it that the protagonist Karl experienced. Canada, the promised land which provided him with shelter, too, is very different from what the emigrant Karl had envisaged, he encounters corruption and immorality in human relations (Kocjančič 2009). After three love relationships that do not work he still cannot find peace and happiness, deceitful love on either side is at the heart of the book and Karl is at the end almost driven into madness: the protagonist's lost youth and the aftereffects of war intermingle with the theme of involuntary migration.

The recent demise of Ted Kramolc, the best known and very prolific literary author of the Slovenian diaspora in Canada, and that of Mirko Jurak, the first and foremost literary critic of this diasporic body of writing both in English and Slovenian alike, represents a big gap in diasporic literature and is yet to be filled by new voices and scholars. 


\section{WORKS CITED:}

Jurak, Mirko. "Uvod" (Introduction). "Literarno ustvarjanje Slovencev v Kanadi” (The Literary Creativity of Slovenians in Canada). Slovenska izseljenska književnost: Severna Amerika. Janja Žitnik and Helga Glušič, eds. Ljubljana: ZRC: Rokus, 1999. 307-383.

. "The Soul Divided: Slovene Immigrant Writers in Canada". Michael Kenneally et al. (eds.). From "English Literature" to "Literatures in English": International Perspectives; Festschrift in Honour of Wolfgang Zach. Heidelberg: Winter, 2005. 195-212.

Kocjančič, Cvetka. "Nove knjige" (New Books). Glasilo 13.2 (March/April 2009): 24.

Kramolc, Ted. Podobe iz arhivov (Images from the Archives). Ljubljana: Mladinska knjiga, 1992. Potica za navadni dan (A Cake for an Ordinary Day). Ljubljana: Slovenska matica, 1997. Tango v svilenih colkah (Tango in Silk Clogs). Ljubljana: Nova revija, 2002.

. "Every Piece of Writing is a Form of Confession". An interview. Slovenia News July 22, 2003.

Sol v grlu (Salt in Throat). Ljubljana: Nova revija, 2008.

Urbančič, Anne. "The Spaces that Define Us”. An interview with Ted Kramolc. Glasilo 12.1 (January/ February 2008): 39-41.

University of Ljubljana 